\title{
PENGARUH BIG FIVE PERSONALITY TERHADAP INVESTMENT DECISION PADA PERUSAHAAN PEER TO PEER LENDING
}

\author{
Helena \\ Program Studi Magister Manajemen Universitas Tarumanagara \\ mshelenlee96@gmail.com \\ Indra Widjaja \\ Program Studi Magister Manajemen Universitas Tarumanagara \\ Masuk : 07-06-2020, revisi : 23-06-2020 diterima untuk diterbitkan : 24-06-2020
}

\begin{abstract}
Investment decision making is a crucial process that is influenced by many factors. This study aims to examine the personality traits that influence investment decisions in Peer to Peer Lending companies. Personality measurements performed by researchers using Big Five Personality Traits, with personality dimensions: Openness to Experience, Conscientiousness, Extraversion, Agreeableness, and Neuroticism. As a result of the hypotheses testing, it was concluded that there was a significant relation between Conscientiousness, Neuroticism with investment decision. However, Openness to Experience, Extraversion, and Agreeableness did not predict investment decision.
\end{abstract}

Abstrak: Pengambilan keputusan investasi merupakan proses krusial yang dipengaruhi oleh banyak faktor. Penelitian ini bertujuan untuk menguji sifat-sifat kepribadian yang mempengaruhi keputusan investasi di perusahaan Peer to Peer Lending. Pengukuran kepribadian yang dilakukan oleh peneliti menggunakan Big Five Personality Traits, dengan dimensi kepribadian: Openness to Experience, Conscientiousness, Extraversion, Agreeableness, dan Neuroticism.Sebagai hasil dari pengujian hipotesis, disimpulkan bahwa ada hubungan yang signifikan antara Conscientiousness, Neuroticism dengan keputusan investasi. Namun, Keterbukaan terhadap Pengalaman, Extraversion, dan Agreeableness tidak memprediksi keputusan investasi.

Keywords: Investment Decision, Big Five Personality, Peer to Peer Lending

\section{PENDAHULUAN}

Investasi merupakan sebuah sarana untuk menempatkan sejumlah uang dengan tujuan uang tersebut akan menghasilkan penghasilan yang lebih tinggi (Smart, Gitman, \& Joehnk, 2005). Tujuan dari investasi yaitu untuk mendapatkan lebih banyak keuntungan. Ada banyak faktor yang mempengaruhi para investor dalam mengambil keputusan investasi. Faktor-faktor tersebut terdiri dari adanya kelebihan dana, pengetahuan dibidang investasi, sifat kepribadian dan pengaruh dari keluarga maupun teman.

Dalam perkembangan teknologi yang semakin canggih telah membawa dampak yang besar diseluruh sektor salah satunya sektor ekonomi. Kehadiran teknologi ini mempermudah segala bentuk transaksi yang menjadi lebih efesien dan efektif. Salah satu kehadiran teknologi yang lagi trending di Indonesia yaitu financial technology (FinTech). FinTech adalah salah satu inovasi teknologi yang bergerak dalam bidang jasa layanan keuangan (www.ojk.go.id). Ada beberapa kategori Fintech yang terdiri dari Peer to peer lending, Market Aggregator, Risk \& Investment Management dan Payment, Settlement, Clearing. Peer to peer lending merupakan salah satu kategori dari FinTech yang mempertemukan antara pemberi pinjaman (lender) dan penerima pinjaman (Borrower). Peer to peer lending menjadi salah satu solusi 
membantu masyarakat untuk lebih mudah memperoleh akses terhadap produk keuangan, mempermudah transaksi dan meningkat literasi keuangan.

UMKM adalah usaha produktif yang dimiliki oleh perorangan maupun badan usaha yang memenuhi syarat-syarat sebagai usaha mikro (Undang-undang Tentang Usaha Mikro, Kecil, dan Menengah, No. 20, 2008). UMKM berperan meningkatkan perekonomian baik dari sisi lapangan kerja dan/atau dari jumlah usahanya dan berkontribusi dalam produk domestik bruto (PDB). Produktivitas pada UMKM yang masih rendah menyebabkan sulitnya mengakses pembiayaan perbankan ataupun lembaga keuangan lainnya untuk sumber permodalan mereka. Karena sebagian besar UMKM dianggap tidak memiliki akses untuk masuk ke bank atau dengan kata lain susah untuk mendapatkan pinjaman dari bank sehingga perbankan cenderung lebih besar perhatiannya terhadap kredit korporasi (Chandra dalam kutipan www.finance.detik.com, 2019).

Permodalan menjadi sebuah kendala yang menjadi fokus utama karena jumlah UMKM yang mampu mengakses permodalan masih rendah. Dengan kehadiran FinTech ini dinilai memiliki potensi memberikan solusi pada permasalahan modal yang di alami oleh pelaku UMKM dengan cara membuka kesempatan untuk mengakses keuangan melalui alternatif pembiayaan yaitu layanan peer to peer lending. Keunggulan dari layanan peer to peer lending yaitu mempertemukan antara borrower dan lender yang mana proses pelaksanaan kesepakatan yang dilakukan secara digital sehingga layanan peer to peer lending ini memenuhi kebutuhan dana secara efisien dan efektif.

Dengan adanya FinTech memberikan akses kepada para lender untuk melakukan pendanaan dengan mudah. Prosedur pendanaan pada peer to peer lending hanya cukup dengan memiliki KTP Indonesia, memiliki smartphone, memiliki rekening dan mempelajari investasi di platform peer to peer lending serta memahami risiko yang berkaitan dengan investasi sehingga dapat membuat keputusan yang baik agar dapat meminimalisir risiko gagal bayar. Pendanaan ke perusahaan peer to peer lending ini juga memiliki kelebihan dibandingkan dengan yang lain,dimana para lender akan memperoleh tingkat suku bunga yang lebih tinggi dibandingkan dengan pendanaan yang dilakukan pada lembaga keuangan lainnya. Namun selain kelebihan peer to peer lending juga memiliki kekurangan yaitu tidak ada lembaga yang menjamin secara hukum terhadap pendanaan yang dilakukan oleh para lender (Ferdiani dalam kutipan www.modalrakyat.id, 2019).

Dalam hal pengambilan keputusan pendanaan dapat dipengaruhi oleh faktor-faktor psikologis dan sosial yang salah satunya adalah aspek big five personality yang meliputi openness to experience, conscientiousness, extraversion, agreeableness, dan neuroticism. Tujuan dari penelitian yang dilakukan adalah untuk mengetahui pengaruh big five personality terhadap investment decision pada perusahaan peer to peer lending.

\section{TINJAUAN PUSTAKA}

Investment merupakan suatu proses bagi para lender untuk menginvestasikan dana ekstranya untuk mendapatkan return yang tinggi. Menurut Smriti Chand (2015) bahwa pengambilan keputusan investasi didasarkan pada beberapa opsi yang untuk dipilih dalam mengambil aksi terbaik sesuai dengan tujuannya.

Menurut Cattel (sebagaimana dikutip dari Engler, 2009) Big five personality adalah kepribadian individu yang menentukan cara bagaimana individu dalam menghadapi situasi yang terjadi padanya. McCrae dan Costa (sebagaimana dikutip dari Feist \& Feist,2009) big five personality atau yang dikenal dengan five factor model sebagai dimensi dari perbedaan individu yang cenderung menunjukkan perbuatan, perasaan, dan pola pikiran yang konsisten. Feist dan feist (2009) big five merupakan salah satu kepribadian yang dapat menjelaskan tentang perilaku individu. Big five personality terdiri darilima dimensi yaitu Openness to experience, Conscientiousness, Extraversion, Agreeableness dan Neuroticism. 
Openess to experience merupakan sifat kepribadian seseorang yang tertarik terhadap halhal baru dan adanya keinginan untuk mempelajari hal-hal baru tersebut. Seseorang dengan kepribadian tersebut akan terobsesi terhadap hal-hal baru yang dimana belum dilakukan oleh individu tersebut (Costa \& McCrae, 1992). Conscientiousness merupakan kepribadian seseorang yang sangat berhati-hati dalam melakukan sesuatu hal baru atau penuh dengan pertimbangan dalam mengambil sebuah keputusan (Costa \& McCrae, 1992). Extraversion dikaitkan dengan tingkat kenyamanan seseorang dalam berinteraksi dengan orang lain (Costa \& McCrae, 1992). Extraversion merupakan individu yang dikenal sebagai pekerja keras, mudah termotivasi, ambisius, mudah berteman, mudah tertantang sekaligus mudah bosan (Friedman \&Schustack, 2006). Agreeableness merupakan individu yang cenderung lebih patuh dan/atau lebih setuju dengan orang lain dan memiliki tipe kepribadian yang menghindari adanya konflik (Costa \& McCrae, 1992). Neuroticism merupakan kepribadian seseorang dalam menahan tekanan atau emosional, sifat positif dari perilaku neuroticism atau yang disebut Emotional Stability yaitu seorang individu dengan emosional yang stabil cenderung akan tenang saat menghadapi masalah. Individu yang mudah gugup, tidak percaya diri, kemarahan dan ketakukan yang dikenal dengan karakteristik negatif dari perilaku neuroticism (Costa \& McCrae, 1992).

Beberapa penelitian terdahulu yang menyatakan bahwa kepribadian Openness to experience, Conscientiousness, Extraversion, Agreeableness dan Neuroticism memiliki pengaruh terhadap keputusan investasi yang diambil oleh investor. Kepribadian conscientiousness dan neuroticism cenderung mendukung untuk pengambilan keputusan investasi (Husnain et al., 2019; Sadi et al., 2011; Kepribadianopenness to experience, extraversion, dan agreeableness cenderung tidak mendukung untuk pengambilan keputusan investasi(Hamza \& Arif, 2019; Pak \& Mahmood, 2013; Mayfield et al., 2008).

\section{METODOLOGI PENELITIAN}

Dalam penelitian ini menggunakan data primer yang didapatkan oleh peneliti melalui hasil kuesioner yang disebarkan kepada responden di wilayah Indonesia melalui media googleform. Penelitian ini menggunakan dua variabel yaitu variabel dependen dan variabel independen. Variabel dependen yang digunakan yaitu investment decision (5 butir pernyataan) dan variabel independen terdiri dari openness to experince (5 butir pertanyaan), conscientiouness ( 5 butir pertanyaan), extraversion ( 3 butir pernyataan), agreeableness ( 5 butir pernyataan), dan neuroticism (3 butir pernyataan). dengan menggunakan skala likert dengan skala 5 poin, mulai dari 1 (sangat tidak setuju) sampai 5 (sangat setuju).

Peneliti memilih untuk menggunakan metode probability sampling. Dengan teknik yang digunakan dalam metode penelitian ini yaitu simple random sampling yang merupakan salah satu teknik dari probability sampling dengan pengambilan sampel yang dilakukan secara acak tanpa memperhatikan strata dalam populasi tersebut.Jumlah kuesioner yang disebarkan sebanyak 317 responden, akan tetapi jumlah kuesioner yang tidak valid sebanyak 15 responden dan kuesioner yang valid sebanyak 302 responden. Kuesioner yang valid akan digunakan dalam analisis data.

Metode analisis data yang digunakan yaitu analisis regresi linier berganda untuk memberikan gambaran mengenai hubungan yang jelas antar variabel independen terhadap variabel dependen dengan tahapan uji statistik deskriptif, uji outlier, uji validitas dan reliabilitas, uji asumsi klasik (uji normalitas, uji multikolinieritas,dan uji heteroskedastisitas), dan uji hipotesis (uji F, uji t, uji koefisien determinasi $\left(\mathrm{R}^{2}\right)$ ).

\section{HASIL \& KESIMPULAN Uji Statistik Deskriptif}

Hasil analisis deskriptif profile responden yang dilihat pada tabel 1 dibawah ini: 
Tabel 1

Profil Responden Penelitian

\begin{tabular}{|c|c|c|}
\hline Jenis Kelamin & Jumlah & Persentase \\
\hline Pria & 133 Orang & $44 \%$ \\
\hline Wanita & 169 Orang & $56 \%$ \\
\hline Usia & Jumlah & Persentase \\
\hline $18-25$ tahun & 239 orang & $79,1 \%$ \\
\hline $26-40$ tahun & 61 orang & $20,2 \%$ \\
\hline $41-55$ tahun & 2 orang & $0,7 \%$ \\
\hline Penghasilan & Jumlah & Persentase \\
\hline$<3$ juta & 126 orang & $41,7 \%$ \\
\hline $3-5$ juta & 62 orang & $20,5 \%$ \\
\hline $5-8$ juta & 37 orang & $12,3 \%$ \\
\hline$>8$ juta & 77 orang & $25,5 \%$ \\
\hline Pekerjaan & Jumlah & Persentase \\
\hline Karyawan & 128 orang & $42,38 \%$ \\
\hline Entrepreneur & 49 orang & $16,23 \%$ \\
\hline Tidak Bekerja & 125 orang & $41,39 \%$ \\
\hline
\end{tabular}

\section{Uji Outlier}

Uji outlier digunakan untuk menguji apakah didalam data yang diolah terdapat data yang meyimpang. Pengujian outlier dilakukan pada 302 responden yang menjadi sampel penelitian. Berdasarkan uji outlier dengan metode Casewise Diagnotics terdapat 25 pengamatan yang memiliki nilai Casewise Diagnotics lebih dari 2,5. Data outlier dikeluarkan dalam penelitian ini. Data sampel yang tersisa sebanyak 277 sampel yang akan digunakan untuk pengujian selanjutnya.

\section{Uji Validitas \& Uji Reliabilitas}

Untuk menguji tingkat kesahihan data dan kehandalan data dilakukan dengan uji validitas dan uji relialibilitas. Berdasarkan uji validitas diperoleh 26 indikator dinyatakan valid karena nilai pearson melebih dari 0,3 . Sementara berdasarkan uji realibilitas menunjukan bahwa semua variabel pertanyaan yang diuji adalah reliabel, karena memiliki nilai Cronbach's Alpha lebih dari 0,06 .

\section{Uji Asumsi Klasik}

Uji asumsi klasik terdiri dari uji normalitas, uji multikolineritas dan uji heterokedastisitas. Berdasarkan uji normalitas yang disajikan dalam grafik normal probability plot yang dapat dilihat pada Gambar 1 yang menunjukkan bahwa titik-titik sebaran data menyebar dan mengikuti arah garis diagonal yang merupakan garis distribusi normal. Sehingga dapat disimpukan bahwa data terdistribusi secara normal. Berdasarkan uji multikolineritas yang dapat dilihat pada Tabel 2 menunjukkan bahwa variabel (openness to experience, conscientiousness, extraversion, agreeableness, dan neuroticism) memiliki nilai tolerance lebih dari 0,10 dan nilai VIF kurang dari 10. Hasil tersebut menunjukkan bahwa model regresi yang digunakan ini tidak terjadi multikolineritas antar variabel independen. Sementara berdasarkan uji heterokedastisitas dapat dilihat pada gambar 2 yang memperlihatkan bahwa titik-titik menyebar di atas dan di bawah angka nol, dan tidak membentuk pola yang teratur. Oleh karena itu, dapat disimpulkan pada model penelitian ini tidak terjadi heterokedastisitas. 


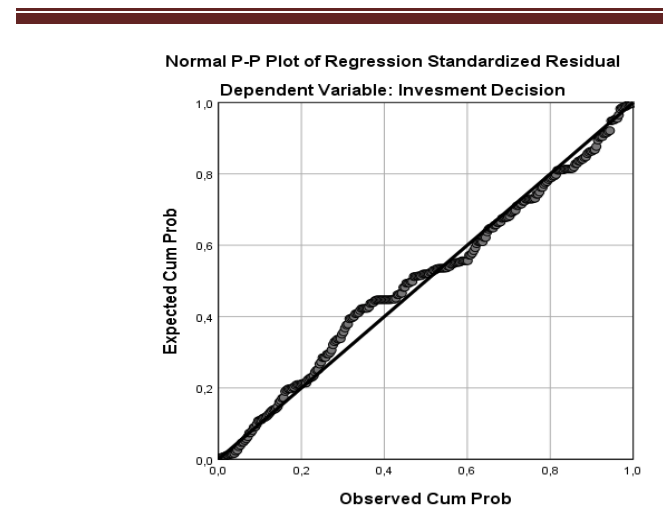

Gambar 1 Normalitas

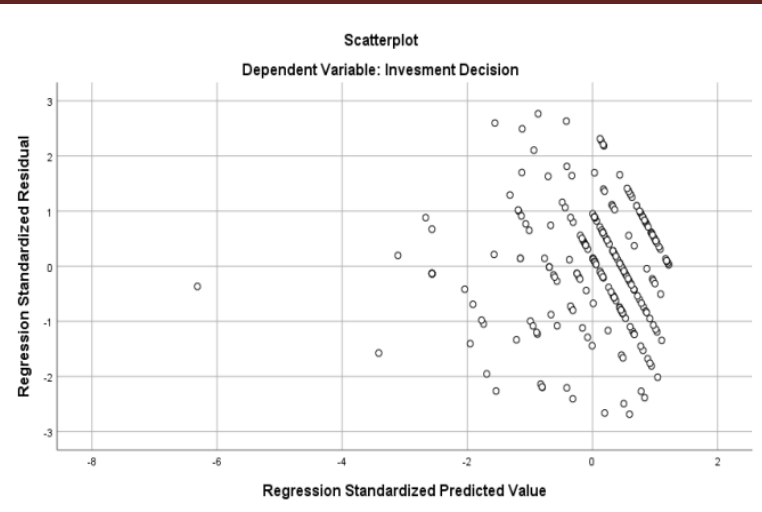

Gambar 2 Heterokesdastisitas

Tabel 2

Multikolinieritas

\begin{tabular}{|l|c|c|l|}
\hline Variabel & Tolerance & VIF & Keterangan \\
\hline Openess to Experience & 0,320 & 3,121 & Tidak terjadi multikolinieritas \\
\hline Conscientiouness & 0,631 & 1,585 & Tidak terjadi multikolinieritas \\
\hline Extraversion & 0,416 & 2,405 & Tidak terjadi multikolinieritas \\
\hline Agreeableness & 0,281 & 3,564 & Tidak terjadi multikolinieritas \\
\hline Neuroticism & 0,432 & 2,317 & Tidak terjadi multikolinieritas \\
\hline
\end{tabular}

\section{Uji Hipotesis}

Uji hipotesis terdiri dari uji $\mathrm{F}$, uji t, dan uji koefisiensi determinasi $\left(\mathrm{R}^{2}\right)$. Berdasarkan uji F menunjukkan angka signifikan sebesar 0,000, Oleh karena itu, dapat disimpulkan bahwa variabel openness to experience, conscientiousness, extraversion, agreeableness, dan neuroticism memiliki pengaruh signifikan secara simultan terhadap keputusan investasi pada perusahaan Peer to peer lending. Berdasarkan uji $t$ menunjukkan bahwa variabel conscientiouness dan neuroticism memiliki pengaruh signifikan terhadap investment decision dengan memiliki nilai signifikansi $<0,05$. Sedangkan variabel openness to experience, extraversion, dan agreeableness memiliki nilai signifikansi lebih dari >0,05 sehingga disimpulkan tidak memiliki pengaruh signifikan terhadap investment decision. Sementara berdasarkan uji $\mathrm{R}^{2}$ nilai adjusted $\mathrm{r}$ square sebesar 0,812 yang artinya $82,1 \%$ variabel openness to experience, conscientiousness, extraversion, agreeableness, dan neuroticism mampu menjelaskan variabel investment decision pada perusahaan Peer to peer lending. Sedangkan sisa sebesar 17,9\% dijelaskan oleh faktor lain yang tidak terdapat dalam model regresi ini.

Berdasarkan hasil analisis data yang telah dilakukan, maka penulis mengambil kesimpulan bahwa conscientiousness dan neuroticism dapat mempengaruhi investor dalam mengambil keputusan investasi pada perusahaan peer to peer lending. Hal ini dikarenakan individu dengan kepribadian conscientiousness akan lebih berhati-hati dalam mengambil keputusan, individu akan melakukan survei terlebih dahulu terhadap perusahaan peer to peer lending sebelum individu mengambil keputusan untuk melakukan pendanaan karena individu tidak bisa toleransi pada investasi yang risiko tinggi. kepribadian neuroticism positif cenderung lebih tenang dalam membuat keputusan dalam pendanaan. Individu akan mencoba mencari informasi sebanyak mungkin tentang perusahaan peer to peer lending, mempelajari semua informasi sebelum mengambil keputusan untuk melakukan pendanaan. Kepribadian openness to experience, extraversion, dan agreeableness tidak mempengaruhi investor dalam mengambil keputusan investasi karena investor cenderung rasional dalam mengambil keputusan investasi. Investor akan mencari informasi tidak cenderung hanya mendengar pendapat dari orang lain. 


\section{DAFTAR PUSTAKA}

Chandra, A. A. (2016). Sulit Dapat Kredit Perbankan Pelaku UMKM Pinjam ke Banyak Pihak. From https://finance.detik.com/bursa-dan-valas/d-3313844/sulit-dapat-kreditperbankan-pelaku-umkm-pinjam-ke-banyak-pihak.

Costa, P. T., \& McCrae, R. R. (1992). Normal personality assessment in clinical practice: The NEO personality inventory. Psychological Assessment, 4(1), 5-13.

Engler, B. (2009). Personality Theories An Introduction ( $8^{\text {th }}$ ed.). USA: Houghton Mifflin Harcourt Publishing Company.

Feist, J., \& Feist, G. J. (2010). Theories of Personality. New York: McGraw-Hill.

Ferdiani, K. R. (2019). Tidak Hanya Peluang Kenali Juga Risiko Peer to Peer Lending. From https://www.modalrakyat.id/blog/tidak-hanya-peluang-kenali-juga-risiko-peer-to-peerlending.

Friedman, H., \& Schustack, M. (2016). Personality: Classic Theories and Modern Research $\left(6^{\text {th }}\right.$ ed.). Pearson Education Inc.

Hamza, N., \& Arif, I. (2019). Impact of financial literacy on investment decisions: The mediating effect of big-five personality traits model. Market Forces College of Management Sciences, 14(1), 43-60.

Husnain, B., Shah, S. Z. A., \& Fatima, T. (2019). Effect of neuroticism, conscientiousness on investment decision, mediation analysis of financial self efficacy. City University Research Journal, 9, 15-26.

Mayfield, C., Perdue, G., \& Wooten, K. (2008). Investment management and personality type. Financial Services Review, 17(3), 219-236.

McCrae, R. R., \& Costa, P. T. (1987). Validation of the five-factor model of personality across instruments and observers. Journal of Personality and Social Psychology, 52, 81-90.

Otoritas Jasa Keuangan. (2016). Peraturan Otoritas Jasa Keuangan Nomor 77/POJK.01/20162016 Tentang Layanan Pinjam Meminjam Uang Berbasis Teknologi Informasi. From https://www.ojk.go.id/id/regulasi/otoritas-jasa-keuangan/peraturanojk/Pages/POJK-Nomor-77-POJK.01-2016.aspx.

Otoritas Jasa Keuangan. (2018). PeraturanOtoritas Jasa Keuangan OJK Nomor 13/POJK.02/2018 tentang Inovasi Keuangan Digital di Sektor Jasa Keuangan. From https://www.ojk.go.id/id/regulasi/Pages/Inovasi-Keuangan-Digital-di-Sektor-JasaKeuangan.aspx.

Pak, O., \& Mahmood, M. (2015). Impact of personality on risk tolerance and investment decisions. International Journal of Commerce and Management, 25(4), 370-384.

Sadi, R., Asl, H. G., Rostami, M. R., Gholipour, A., \& Gholipour, F. (2011). Behavioral finance: The explanation of investors' personality and perceptual biases effects on financial decisions. International Journal of Economics and Finance, 3(4), 234 - 241.

Smart, S., Gitman, L., \& Joehnk, M. (2014). Fundamentals of Investing (13 ${ }^{\text {th }}$ ed.). Boston: Pearson.

Smriti, C. (2015). Decision making: 7 step involved in decision making. Business Management. Undang-undang Tentang Usaha Mikro, Kecil, dan Menengah, No. 20, (2008). 